\title{
Cost and Benefit from Development The Infrastructure of Southern Cross Roads (“Jalur Lintas Selatan or JLS") (Studies of Malang Roads)
}

\author{
Herman Cahyo Diarto*, Maryunani*, Sasongko*, Khusnul Ashar* \\ *(Economics, Brawijaya University, Indonesia)
}

\begin{abstract}
The important ones of region development is built infrastructure. In the open economy era, infrastructure is one of the development economy needs, in particular roads infrastructure. Lastly, many research concern about conflict between infrastructure development and environmental. This study explained about cost and benefit from development infrastructure in Southern Malang, which name Southern Cross Roads $(J L S)$. The infrastructure development (JLS) in Malang has converted protected forest about 148,140 hectare be the roads. This is reflected about interaction between economy aspect and ecology aspect. This study using Cost-Benefit Analysis and Contingent Value Method which measured from Willingness to Pay (WTP) and Willingness to Accept (WTA). The result of this research indicated that the conversion of protected forest to road has led to decrease in the economic and ecological benefits of forest protection, depletion natural resources of protected forest, environmental degradation, and the cost and the benefit of JLS development is unbalance.
\end{abstract}

Keywords: Infrastructure development, Environmental, WTP, WTA.

\section{Introduction}

Road transport infrastructure is the kind of infrastructure that determines the development of a region. In fact the spillover effects of infrastructure investment on economic growth in the region not only affect themselves but also have an impact on surrounding areas or neighbors (Calderon, 2004). The importance of road infrastructure in the region's development is also supported by Rietveld and Nijkamp (2000) which states that the development of the region is determined by a combination of factors of production proper, such as labor and capital, and also the infrastructure in general, particularly transportations. Kasikoen (2005) suggests that infrastructure facilities such as roads, bridges, communications, markets, schools and clean water are essential elements as the prime mover foundation to supporting the development of the region.

Infrastructure development also affects to the socio-economic condition of the people in a country. It can be explained by De La Fuente (2002), adequate infrastructure will improved quality of life, moreover demand for infrastructure services and other public services will increase with increasing public expectations to get public services (Hudson, et al, 1997), Infrastructure contributes significantly to improve the quality of people's lives, Demurger (2001) geographical location and infrastructure endowment significantly explain the differences performance of decision makers.

The importance of road infrastructure for the national economy empirically is verified by regional development disparities. The gap region between Java (KBI) and outside Java (KTI), between regions in the island, as well as between urban and rural areas that caused by the lack of road infrastructure factors. Empirically occurs an imbalance between the regional development North Coast of Java (PANTURA) and South Coast of Java (PANTESA). The condition of the roads in the Northern region of Java (PANTURA) has been able to lift the economy, social activities, and mobility of citizens, while due to limited road infrastructure in the southern region of Java, the development of the region and the level of social welfare is still low even found many isolated areas.

Southern Cross Roads, Jalur Lintas Selatan (JLS), in East Java Province was initiated from 2006 to present, newly realized along the $300 \mathrm{~km}$. JLS development involves three parties, the District Government in charge of the land acquisition, Province Government who do physical work and the preparation of the road, and the central government who do the foundation of stone, the foundation of asphalt and layer of the road surface. By the end of 2010 four sections JLS in East Java Province along the 300 miles already be utilized, namely Pacitan-Hadiwarno, Popoh-Prigi, Balekambang-Sendangbiru and jarit (Lumajang)-Puger (Jember). (East Java Provincial Highways, 2010).

One area which is crossed by JLS infrastructure development segment of East Java Province is a South Malang which past three districts namely: District Sumbermanjing Wetan, Gedangan and Sumbermanjing Kulon. Sub-districts are functionally heterogeneous region that means all three have different socio-economic 
characteristics and potentials. The economic potential of the region is crossed by construction of the Southern Cross in Malang include fisheries, tourism, forestry, dry land agriculture and forests.

One of the non-economic factors considered, namely environmental sustainability. The important of preserving the natural environment in the process of economic development supported by Menlh. Menlh (2011) explain the importance of economic development based on ecological economics and green economics that aims to address the interdependence between economic development and ecosystems. The quality of environmental in regions relates to many factor, such as the regional environment background, human activities and the regional self-purification capacity (Haiping, W, et al, 2011)

One of the important issues facing economic development is how to deal with the trade off between development needs and maintaining environmental sustainability. Trade off between employment, technology, and environment in the process of economic development (Karshenas, 1994) Investment of JLS infrastructure development in Malang must be made to support the successful development of the region. JLS in the southern of Malang became object to study the concept of sustainable development (sustainable development paradigm) caused by three goals to be achieved, namely: economic growth areas (economics growth), construction of a just social welfare and evenly (social progress) as well as ecological sustainability (ecological balance).

Based on the background this research aims to examine the benefits and costs of the Southern Cross Road (JLS) infrastructure development in protected forest areas in South Malang from the value of Willingness To Pay (WTP) and Willingness To Accept (WTA).

\section{Research Methods}

The Research location in the South Cross Roads segment, Malang, East Java, Indonesia. Using Cost Benefit Analysis (CB-Analysis) and CVM (Contingent Value Method). Measure the different types of socioeconomic models is dealing with Cost Benefit analysis(CB-Analysis) (Johansson, 2004). Technically this analysis are measured by the value of Willingness To Pay (WTP) and Willingness To Accept (WTA). A contingent Value Method is utilized in this study to measure the Willingness To Pay (WTP) (Raghu, et al, 2009).

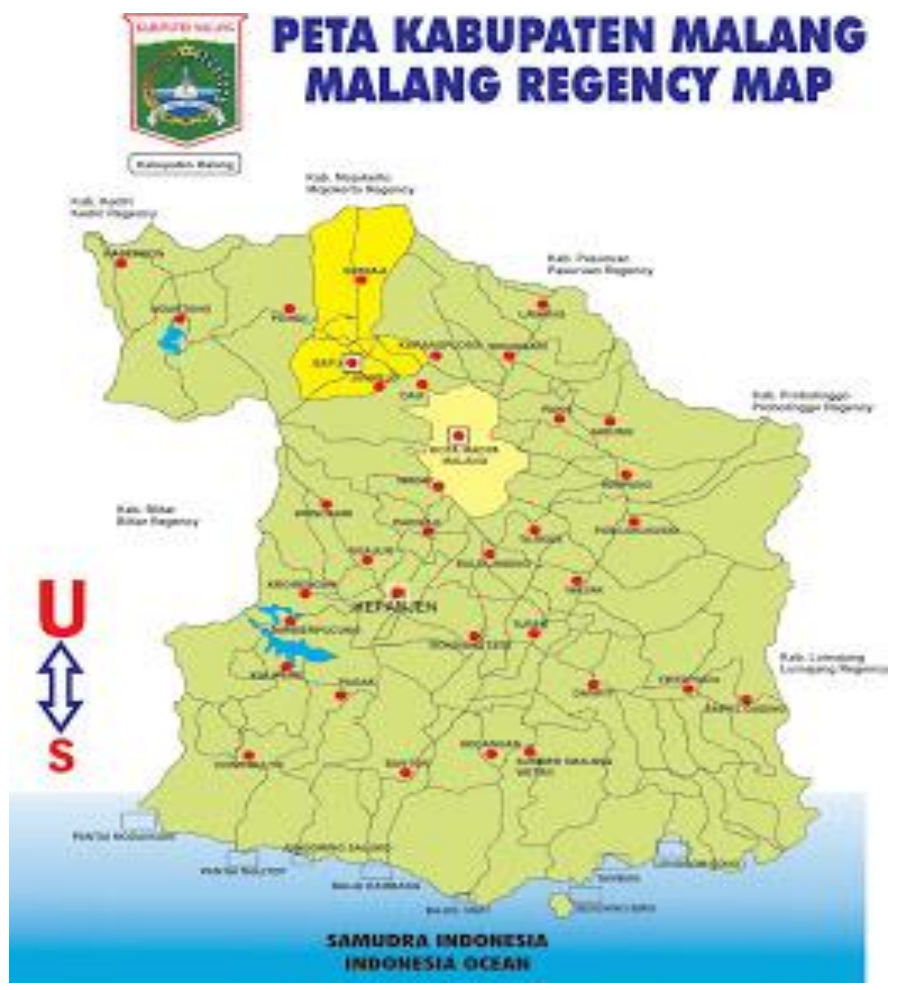

Fig. 1. Research Location Map

III. Empirical Result

Economical development and environmental protection seem like forever rival to each other (Yungfeng and Guohui, 2012). In this Case, analyst of Changes benefits from protection forests are perceived by villagers after the construction of JLS. The value of the benefits from the forests began to decline to give effect to the revenue earned by the forest villagers. This result indicate that JLS infrastructure development reduce the benefit of forest and benefit of land forest. Changes in the value of the direct benefits of protected forests and 
revenue received by the immigrant communities and local forest conditions before and after the JLS infrastructure development can be seen in the table below.

Table.1. Changes in Value of Benefit

\begin{tabular}{|l|l|l|l|l|}
\hline No & \multicolumn{1}{|c|}{ Forest Conditions } & $\begin{array}{c}\text { Benefit Of } \\
\text { Forest }\end{array}$ & $\begin{array}{c}\text { Benefit Of Land } \\
\text { Forest }\end{array}$ & $\begin{array}{c}\text { The Amount of benefit is } \\
\text { received by the } \\
\text { community }\end{array}$ \\
\hline \multirow{2}{*}{1} & Before JLS & \multicolumn{3}{|l|}{} \\
\cline { 2 - 5 } & a. Immigrant (74 KK) & 38.492 .000 & 27.450 .000 & 65.942 .000 \\
\cline { 2 - 5 } & b. Local (253 KK) & 21.408 .000 & 29.000 .000 & 50.408 .000 \\
\cline { 2 - 5 } & Total & 59.900 .000 & 56.450 .000 & \\
\hline \multirow{2}{*}{2} & After JLS & 15.838 .000 & 16.200 .000 & 32.038 .000 \\
\cline { 2 - 5 } & a. Immigrant (74 KK) & 11.000 .000 & 15.260 .000 \\
\cline { 2 - 5 } & b. Local (253 KK) & 4.260 .000 & 27.200 .000 & \\
\cline { 2 - 5 } & Total & 20.098 .000 & & \\
\hline
\end{tabular}

Source: primary data, 2012

Comparison of the value of direct benefits protected forest, the condition before and after the development of Malang JLS can be seen below:

Table.2. Direct and Indirect Benefit

\begin{tabular}{|l|l|l|l|l|l|}
\hline No & \multicolumn{1}{|c|}{ Benefit Value } & Before JLS & After JLS & $\begin{array}{c}\text { Different } \\
\text { benefit value }\end{array}$ & Percentage \\
\hline \multirow{2}{*}{1} & Direct benefit of protected forest & \\
\cline { 2 - 6 } & Forest Benefit & 59.900 .000 & 20.098 .000 & 39.802 .000 & $(66,44)$ \\
\cline { 2 - 6 } & $\begin{array}{l}\text { Benefit of The land } \\
\text { Forest }\end{array}$ & 56.450 .000 & 27.200 .000 & 29.250 .000 & $(51,81)$ \\
\cline { 2 - 6 } & Total & 116.350 .000 & 47.298 .000 & 69.052 .000 & $(59,34)$ \\
\hline \multirow{2}{*}{2} & \multicolumn{4}{|l|}{ The Amount of benefit is received by the community } & \\
\cline { 2 - 6 } & a. Immigrant & 65.942 .000 & 32.038 .000 & 33.904 .000 & $(51,41)$ \\
\cline { 2 - 6 } & b. Local & 50.408 .000 & 15.260 .000 & 35.148 .000 & $(69,72)$ \\
\cline { 2 - 6 } & Total & 116.350 .000 & 47.298 .000 & 69.052 .000 & $(59,34)$ \\
\hline
\end{tabular}

Source: primary data, 2012

This table explains that JLS infrastructure development has led to a decline in the value of direct benefits from protected forests are accepted by society. Decline in the value of the direct benefits Rp69,052,000 is incurred by migrants and local communities so that changes in the value of these benefits to the costs borne by society in the areas of debt protected in South Malang. The development economy and the protection environment, sometimes, are contradictory in particular in short-term (Guo, L and Ma, H, 2008)

The results of the identification of all the benefits of forest protection in South Malang in before and after the construction JLS no development described above, then performed the quantification of all benefits. Details of the value of the benefits of each can be seen in the table below.

Table.3. Value of Benefit

\begin{tabular}{|l|l|l|l|}
\hline \multirow{2}{*}{ No } & \multirow{2}{*}{ Kind of Benefit } & $\begin{array}{l}\text { Benefit Value } \\
\text { (Million Rupiahs/ years) }\end{array}$ & $\begin{array}{l}\text { Benefit Value } \\
\text { (Million Rupiahs/ years) }\end{array}$ \\
\cline { 3 - 4 } & & Before JLS & After JLS \\
\hline 1 & Direct Benefit & 116.350 .000 & 47.298 .000 \\
\hline 2 & Non Direct Benefit & 52.800 .000 & 24.000 .000 \\
\hline 3 & Existence Benefit & Rp 1.533.616 & 0 \\
\hline & Total of economy value & 170.683 .616 & 71.298 .000 \\
\hline & Different value benefit & 99.385 .616 & \\
\hline
\end{tabular}

The table explains that the decline in the total economic value of protected forest after the JLS infrastructure development. Changes in value due to the construction of JLS as indicators of ecosystem and the changing environment of protected forest areas. This value is explained that the difference in value of forest benefits before and after the construction of JLS is Rp99,385,616. That means, changes in the condition of 
ecosystems and environmental quality in the area of protected forests in South Malang by $139.39 \%$, due to the construction of JLS.

The change of value of the benefit will describe damage ecological functions are protected as a conservation area should be kept to the continuity. Damage to ecosystems and the environment in protected forest areas by $139.39 \%$ to the costs incurred to the construction of infrastructure in the area JLS of South Malang. This be in contradiction with several argument which tell that the very nation of sustainable development refers to some self regeneration capacity of ecosystem (Daly, 1990,1991; Bertinelli et all, 2006)

The results of the benefits and costs of infrastructure development in the area JLS of Malang further integrated with investment and economic costs (borne by society). The result of Cost Benefit analysis as follows:

Table.4. Cost Benefit Analysis Result

\begin{tabular}{|l|l|l|}
\hline \multicolumn{1}{|c|}{ PV Cost } & \multicolumn{1}{|c|}{ PV Benefit } & \multicolumn{1}{c|}{ Net Benefit } \\
\hline 527.674 .668 & 1.304 .312 .988 & 776.638 .320 \\
\hline 695.117 .023 .489 & 544.837 .927 & 694.572 .185 .563 \\
\hline 694.589 .348 .821$)$ & 759.475 .061 & $(693.795 .547 .243)$ \\
\hline$(1) /$ negative & 1 & $(1) /$ negative \\
\hline
\end{tabular}

The results of the Cost Benefit analysis is negative one, indicates that the economic development of infrastructure in the area JLS of Malang unprofitable in the short outreach (at the time the study was conducted).

Described above occurs degradation depicting the environment and the behaviors that lead to eating forest resources should be implemented control instruments. One of them is to balance the concept of Willingness to Accept (WTA) and Willingness to Accept (WTA).

WTA value of Southern Cross Road infrastructure development that has converted forest in South Malang region of Rp 46,077. WTP values of the community as the recipient of Rp 251,441.

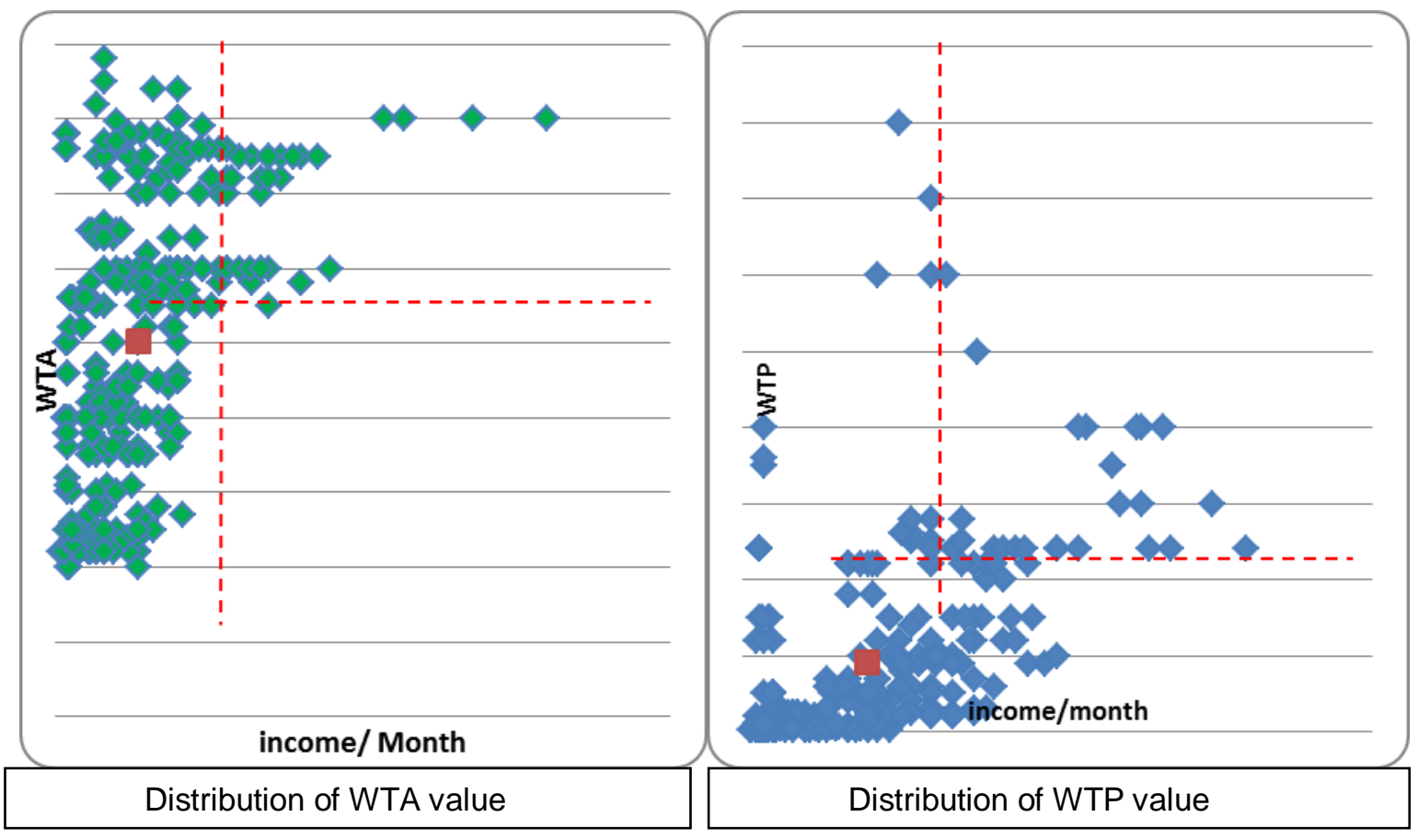

Fig.2. Distribution of WTA and WTP Value

People have the perception that the construction of JLS has many benefits, ranging from the easy accessibility to the increased activity of economists. The benefits of infrastructure development in the area JLS of Malang can be seen in the table below. 


\section{Table.5. Benefit Aspect that Received}

\begin{tabular}{|l|l|l|}
\hline Benefit aspect that received & Sum & $\%$ \\
\hline The numbers of saving customers increasing & 3 & $0.96 \%$ \\
\hline The numbers of credit customer increasing & 2 & $0.64 \%$ \\
\hline The numbers of hajj saving increasing & 2 & $0.64 \%$ \\
\hline The numbers of transfer transactions increasing & 1 & $0.32 \%$ \\
\hline The numbers of fishery transactions increasing & 6 & $1.92 \%$ \\
\hline The community that saving and credit increasing & 2 & $0.64 \%$ \\
\hline Expand the market & 22 & $7.05 \%$ \\
\hline Facilitate accessibility & 86 & $27.56 \%$ \\
\hline Facilitated security control environment & 7 & $2.24 \%$ \\
\hline Build the religious and the culture tourism & 10 & $3.21 \%$ \\
\hline Reduce transportations cost & 27 & $8.65 \%$ \\
\hline Increasing income & 2 & $0.64 \%$ \\
\hline Increased aid reforestation seedlings & 5 & $1.60 \%$ \\
\hline Rising rents or boarding house & 6 & $1.92 \%$ \\
\hline Increasing the member of credit & 3 & $0.96 \%$ \\
\hline Increasing the numbers of customers & 4 & $1.28 \%$ \\
\hline Increasing the numbers of tourist & 14 & $4.49 \%$ \\
\hline Increasing public awareness of greening & 3 & $0.96 \%$ \\
\hline Increased the profit land & 6 & $1.92 \%$ \\
\hline Increased business profit & 71 & $22.76 \%$ \\
\hline Increasing community training & 4 & $1.28 \%$ \\
\hline Increased income & 12 & $3.85 \%$ \\
\hline Increased demand for fertilizer & 9 & $2.88 \%$ \\
\hline Rising gold pawn transactions & 5 & $1.60 \%$ \\
\hline S & & \\
\hline
\end{tabular}

Source: Primary data in September 2012

Willingness to Accept (WTA) reflects the value of the loss to be borne by an individual of the community as a result of environmental damage caused by the conversion of protected forest into the road. The table below is an acceptable loss aspect of society from JLS development in South Malang.

Table.6. Aspect of The Acceptable Loss

\begin{tabular}{|l|l|l|}
\hline \multicolumn{1}{|c|}{ Aspect of the acceptable loss } & Total & $\%$ \\
\hline Flood & 2 & $0.58 \%$ \\
\hline Rots of mud flows & 12 & $3.50 \%$ \\
\hline Reduce income & 77 & $22.45 \%$ \\
\hline Lotuction in mud feaf green manure & 19 & $5.54 \%$ \\
\hline Loss of attractiveness beauty of the forest & 17 & $4.96 \%$ \\
\hline Lots of mud flows and erosions & 68 & $19.83 \%$ \\
\hline Reduce the quality of water & 5 & $1.46 \%$ \\
\hline Environment easily to flooded & 4 & $1.17 \%$ \\
\hline Reduced the water in the dry season & 7 & $2.04 \%$ \\
\hline Frequent flooding & 23 & $6.71 \%$ \\
\hline Hot temperature & 7 & $2.04 \%$ \\
\hline Water sources dry up & 47 & $13.70 \%$ \\
\hline Land easily to erosion & 4 & $1.17 \%$ \\
\hline Strong sea wind pressure & 12 & $3.50 \%$ \\
\hline Soun & 39 & $11.37 \%$ \\
\hline
\end{tabular}

Sources: primary data in the September 2012

The analysis of field data from Southern Cross Road (JLS) infrastructure development in South Malang that has converted forestland protected infer the occurrence of the process of depletion and degradation of natural resources in three zones. It is explained that economic activity in this case is the construction of the 
road that can't be separated from the existence of a landscape (resources system / resources stock) in the South Malang. At the opposite extreme, the ecologists' pessimistic view was counteracted by a position according to which the fastest road to environmental improvement is along the path of economic growth: higher incomes increase the demand for less material-intensive goods and services; at the same time higher incomes bring about an increased demand for environmental protection measures (Galeotti M, 2003)

The theoretically Southern Cross Road infrastructure has converted the protected forest is a conflict between microeconomic theories to the theory of environmental economics. Therefore, to answer the phenomena of degradation and depletion of natural resources after the construction of the JLS infrastructure is necessary dialectical process between the two theories. The results of the dialectic between economic theory and economic theory related to environmental degradation and resource depletion caused after the JLS infrastructure development in South Malang region as follows:

1. Degradation of natural resources (NR) occurs due to the separation between the system and the system of scarcity pricing, benefits and costs, rights and responsibilities, actions and the consequences

2. Degradation of natural resources occurs not due to construction activities (construction JLS), but because of the occurrence of errors and failures in policy and market failures.

3. Amendments to the phenomenon of market failure from depletion and degradation of natural resources in the area of South Malang market can be done through certification of rights to natural resources, especially land rights, licensing is done in an open and competitive, pricing of land and water better, subsidizing positive externalities (the provision of educational facilities, parks), taxes on rents (surplus profit) from natural resources such as land rent and water resource

Empirically factors that caused natural resource damage as a result of construction activities for infrastructure development especially Southern Cross Road in South Malang is the activity of a powerful class of capital owners both socio-political and economic have exploited natural resources. They are generally a group that has an abundance of resources and rights (property rights) are very strong and have easy access to power. In contrast, those who received a negative impact (social cost) is poor people who have no rights or their rights are very weak. Problems degradations and natural resources in South Malang characterized the distribution of economic benefits and costs (social costs) are not balanced. The economic benefits are generally accepted by the group of strong while many social costs must be borne by the weaker segments of society that the poor majority.

Thus it is clear that the differences in the rights (entitlement) is very conspicuous among the various levels of society to be one of the principal causes that gave rise to the issue of natural resources and the environment. Therefore any policy that could lead to the equalization of rights and incomes and reduce poverty, will indirectly lead to improved sources of natural resources and the environment. Degradation of natural resources in South Malang as too centralized authority / power rights in resource management systems-natural resources, whether the resource is in the form of forest and marine resources and agriculture.

These natural resources especially forest resources and marine / coastal areas are 'open access' or quasi open access resources are all aimed at maximizing the benefits of these natural resources, while none would maintain continuity so eventually suffer degradation and depletion of natural resources. This phenomenon is described by Garrett Hardin (1968) known as "The Tragedy of Commons". Tragedy can happen because the state resources that is "Open Access".

Depletion and degradation of natural resources and the environment that occur after the Southern Cross Road infrastructure development in Malang district that includes quantity and quality, such as:

1. The issue of groundwater resources, at some point in the dry season farm and forest zones of water shortage and damage due to disruption of system quality in the upper catchment.

2. Problems experienced deforestation forests (deforestation) caused by the loss of forest cover (forest cover) and forest degradation caused by decreased productivity and diversitasnya as happened in the process of changing primary forests to secondary forests and grasslands.

3. Land has a role related to the economic, ecological and socio-cultural. One problem area is characterized by a growing scarcity of land resources due to a problem is the structure of ownership (property rights) or too much land arrangements are not well coordinated land use does not lead to achieve optimal use. The structure of ownership (property rights) to land greatly affect quality because if the rights or property right to land was uncertain (uncertain), the state in turn encourages the reduction of maintenance of land that leads to the decline of quality land (fertility). Character on land use in the area of South Malang resulted in an increase in the number of farmers forest encroachers with the condition of land rights is uncertain. They are working on state forest land, including forests. In seaboards and conversions zone for coastal lands into farms has led to increased erosion and flooding and the loss of resources, the beach / ocean.

4. In the coastal zone in particular on fisheries resources that are open access (open access), symptoms of over fishing and mangrove deforestation. Factors that lead to over Fisihing due to the use of advanced 
technologies such as trawl nets and long net. Excess catches for species of commercial species causes changes in species composition to the composition of the less valuable that lead to the situation that greatly reduces the value of water resources.

The process of depletion and degradation of natural resources that occur after the Southern Cross Road infrastructure development in Malang started with the easy accessibility of transportation to and from the forest zone, agricultural zone and the coastal zone. Ease of accessibility causes decreased transportation costs that drive increased demand (demand) on natural resources as consumer goods, basic materials industry and regional economic development. In another aspect of inventory (supply) natural resources are relatively fixed. The gap between the demand with the supply of the natural resources directly cause increased scarcity of natural resources and environmental damage that occurs increasingly severe and continuing from time to time.

The issue of natural resource scarcity and environmental degradation exacerbated further by the incapacity within its organization system, both concerning the organization of economic and social institutions. These deficiencies are reflected mainly from the inability to establish a system of economic organization, especially in carrying out various adjustments required as a result of the dynamic changes that occur in the community, particularly with regard to economic growth.

Areas that fall into the category backward development to encourage the development of the necessary instruments of road infrastructure. JLS infrastructure development in the area of South Malang is expected to contribute positively encourage the development of the region. South Malang regional development besides economic aspects should pay attention to non-economic aspects should also be considered. As the region has a landscape (system resources / resources stock) crossed by infrastructure development JLS environmental aspects should also be considered in planning the development of the region. This means in planning the construction of the South Malang development paradigm used is sustainable development (sustainable development).

Sustainable development is a concept addressing the needs of humans to improve the well-being through the use of natural resources without reducing the potential for future generations to use these resources. Therefore, the sustainable development paradigm is the exchange (trade-off) between the current generation with the generations to data in utilizing natural resources to improve welfare (Bell and Morse, 2003). Setiawati, et al (2013) told that the Institutions, environment, technology selection, financial/economy and socio-cultural conjointly affect the sustainability.

Munasinghe (1993) told that sustainable development has three objectives namely economic, social, and ecological purposes. The relationship between the three objectives and essential elements that must be considered in achieving these goals can be seen in the picture below.

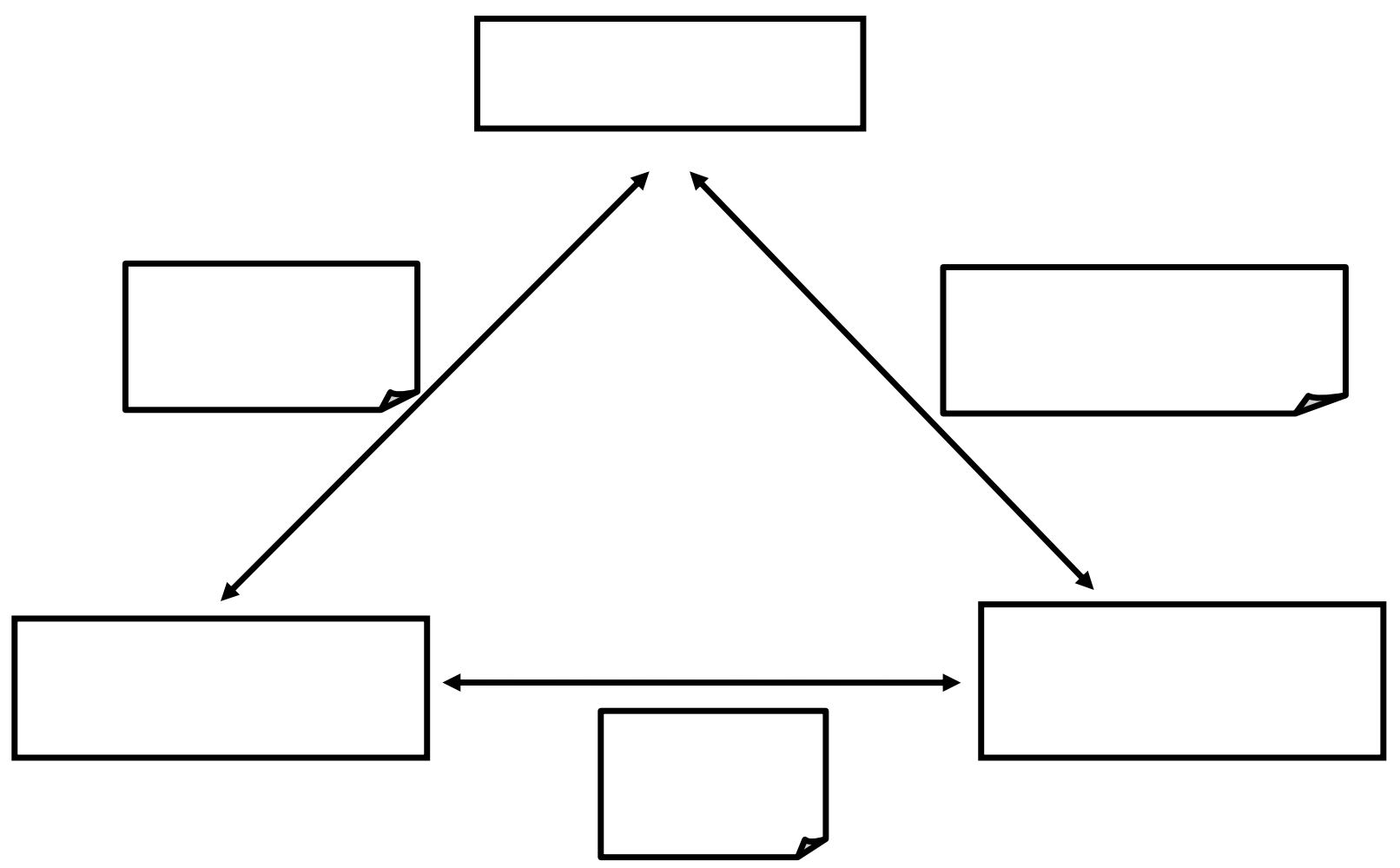

Fig.3. Substance of Sustainable Development 
In the picture above explains that the paradigm of sustainable development has three goals interact, namely social, economic and ecological. Based on the picture above, the Southern Cross Road infrastructure development that has converted forest in South Malang when analyzed with the sustainable development paradigm with the following results:

\section{The purpose Economic and Social Goals}

Southern Cross Road infrastructure development in South Malang has two dimensions interrelated objectives, namely economic and social objectives. Socio-economic objective has three essential elements that must be taken to ensure that objectives can be achieved simultaneously, the distribution of income, employment (employment), and targeted assistance (targeted assistance). JLS infrastructure development should be able to have an impact on the expansion of job opportunities in all sectors. Expansion of employment opportunities should also be accompanied by the distribution of income received by all people equally in all zones. To that end, any obstacles (barriers) that impede access to the community, especially the poor to participate in development and utilization of natural resources JLS after the infrastructure development in South Malang have is minimized or eliminated altogether.

Social goals to be achieved in infrastructure development in the area JLS of South Malang was the realization of a balanced social life in the forest zone, agriculture and coastal. The realization of a balanced social life indicators, as follows (Global Eco-village Network, 2007):

1. Realization of social stability in people's lives so that security and confidence occurs that gives people the freedom to express themselves for the common good,

2. The availability of space and the systems that support and maximize communication, relationships and productivity,

3. There is the opportunity / technology enough to communicate in the community and to connect with the public in a timely,

4. Talents, skills, and other community resources freely exchanged within the community and outside the community offered to provide better service,

5. Diversity is respected as a source of health, vitality and creativity in the natural environment and the community relationships,

6. Acceptance, democracy and openness facilitate the understanding of the importance of diversity, enrich experience and enhance social and environmental justice,

7. Individual growth, learning and creativity cherished and nurtured. Opportunities for learning and teaching available to all age groups through a variety of education formats,

8. Options to repair, maintain or improve health (physical, mental, emotional and spiritual) are available and affordable community,

9. The flow of resources in terms of giving and receiving of capital, goods and services, can balance the needs and desires of the community,

10. Creating a local economy that can compete and have minimal impact on the environment

\section{The purpose and aim of Economic Ecosystem}

Development activities aimed to promote regional development in South Malang through Southern Cross Road infrastructure has relevance to the systems of natural resource management and environmental sustainability. Response and the acceleration of economic development requires the maintenance of the environment that supports economic activity and social dynamic. Development in the area of South Malang will not grow rapidly in the socio-economic life of the region is not dynamic and full of uncertainty. Trends in regional economic development if it does not take into account is the value of natural resource use, such as the intrinsic value of natural resources and social burden due to resource use will be a failure. (WH Freeman.1990, Scientific American and Managing Planet Earth, New York).

Limited natural resource assessment system will create its own externalities (especially negative externalities) which is very detrimental to society as a whole. The public should bear the burden / social costs arising in any use of natural resources without any given 'compensation'. Load / biggest social costs borne by society today and in the future is the decline in the quality of life and the environment, which of course does not guarantee long-term sustainable resource management (ecosystem objectives in sustainable development is not achieved). Therefore, the development of infrastructure in the area JLS of South Malang aimed at the development of the area should be the objective of the ecosystem. Programs and development activities in the area of South Malang first be evaluated impact on the environment. In addition, an assessment of the natural resources used (both extrinsic and intrinsic value) is necessary to avoid, at least reduce, the externality. If externalities has occurred, then the efforts internalizing the effects out (externalities) this should be done, for example, with other forms of compensation. Thus, any activity intended to promote economic growth or efficiency of capital (economic objective) will continue to pay attention to sustainable resource management. 


\section{Social Goals and Objectives Ecosystem}

Management of natural resources and the environment after the infrastructure development in the area JLS of South Malang must be based on the policy environment that emphasizes the aspects of conservation and protection of natural resources. The policy must also take into account the people who still depend on these natural resources especially in the forest zone and the coastal zone. If that is not addressed will have a negative effect on poverty and affect the long-term success in the conservation of natural resources and economic development in the area of South Malang. Poverty is one of the social problems are closely related to the efforts of sustainable management of natural resources in the South Malang. This shows that if you want to make the effort of natural resource management for sustainable development of the region - for example, through land conservation, land, forest cover, and water - the population problem cannot ignored. Conservation and environmental controls must be accompanied by efforts to suppress the high population growth rate. In addition, the issue of property rights is a decisive factor in the efficient use of natural resources, equitable, and sustainable. Resources owned by the public (it is not clear right of ownership) has led to an open access resource, in this situation anyone can take advantage of the natural resources without even having the incentive to maintain sustainability.

Wisdoms that exist in local communities in the forest zone, the coastal farming and traditional knowledge should be understood and used as a base to make infrastructure development activity, especially after JLS in South Malang. To the end, local communities, which runs as the traditional knowledge that is in the landscape (system resources / resources stock) should be included in the implementation of development programs. If this can be done and realized the active participation of local communities in the development would present itself so that it will be able to preserve the natural resources and the environment in South Malang.

\section{Conclusions}

This study aims to explain the costs and benefits of the Southern Cross Road (JLS) infrastructure development in South Malang. The end result of this research resulted in several conclusions, among which are:

1. Protected forest conversion into JLS infrastructure in South Malang region has led to decrease in the economic and ecological benefits of forest protection for 640056160212 or $88.8 \%$.

2. Forest zone

In the forest zone after the infrastructure development in the area JLS of South Malang the depletion of natural resources from protected forests and forest products amounted to $59.34 \%$ of forest land.

3. Coastal-marine zone

Potential of fishery in coastal zone of South Malang is still in a state of under exploitation.

4. Agricultural zone

In the agricultural zone illustrates a shift in the governance of agricultural land followed by changes in environmental quality that lead to environmental degradation.

5. JLS infrastructure development in South Malang area causes the distribution of economic benefits and costs (social costs) are not balanced

\section{References}

[1]. Bell, S. \& Morse, S., 2004, Delivering sustainability therapy in a projectified world-plenary presentation,in:The 2004 International Sustainable Development Research Conference (Manchester: Hulme Hall, University of Manchester, ERP Environment).

[2]. Bell, S. \& Morse, S.,2003, Measuring Sustainability: Learning by Doing (London: Earthscan), 1(4), pp. 193-218.

[3]. Berteneli, L, et. al, Sustainable Economic development and The Environment: Theory and Evidence, Core Discussion Paper,2006

[4]. Calderon, C. And Serven, L, The Effects of Infrastructure Development on Growth and Income Distribution, 2004

[5]. Daly, H, Towards an Environmental Macroeconomics, Land Economics 67, 1991, 255-259

[6]. De la Fuente, Angel, On the sources ofc onvergence: A close look, at the Spanish regions accepted 1 April 2001

[7]. Daly, H, Towards Some Operational Principle of Sustainable Development, Ecological Economics 2, 1990,1-6

[8]. East Java Province Highways, Pembangunan Jalan Lintas Selatan (JLS) Jawa Timur, 2010

[9]. Galeotti Mario, Economic Development and Environmental Protection, Nota Di Lavoro 89, 2003

[10]. Garrett Hardin, The Tragedy of the Commons, Source: Science, New Series, Vol. 162, No. 3859 (Dec. 13, 1968), pp. 1243-1248

[11]. Global Ecovillage Network (GEN), Sociality balances, 2007

[12]. Guo, Longlong, and Ma, Hongbo, Conflict between Developing Economic and Protecting Environment, Journal of Sustainable Development Vol.1, 2008, 91-97

[13]. Haiping, W, et al, Analysis on the Environmental Conditions for Economic Development in Central China, Energy Procedia, 2011, 1234-1250

[14]. Hudson, B. Hardy, B. Henwood, M. and Wistow, G., 1997a, Inter-Agency collaboration: fi nal report Leeds: Nuffi eld Insitute for Health Community Care Division

[15]. Johannson, S, Socio-Economic Impact of Road Condition on Low Volume Roads (Northern Peripery, Roadex II Project, 2004)

[16]. Karshenas, M. Environment, Technology and Employment:Towards a New Definition of Sustainable Development.Jounal Development and Change Vol 2,1994, 723-756

[17]. Kasikoen, K.M, Kajian Keterkaitan Perkotaan - Perdesaan Di Jawa Barat, Diss Institut Pertanian Bogor, 2005

[18]. Managing Planet Earth: Readings from Scientific American Magazine, 1990. W.H. Freeman and Company, New York, NY. 146 pages. ISBN: 0--7167-2108 
[19]. Menlh. Menuju Green Economy : Pertumbuhan Ekonomi Versus Pembangunan Lingkungan, 2011

[20]. Munasinghe, M. 1993. Environmental Economics and Sustainable Development. World Bank Environment Paper Number 3. The World Bank, WashingtonDC.

[21]. Nijkamp P, Rietveld P, Spierdijk L, "A meta-analytic comparison of determinants of public transport use: methodology and application" Environment and Planning B: Planning and Design 27(6), 2000, 893 - 903

[22]. Nijkamp, P; Ubbels, B; Verhoef, E; (2002). Transport Investment Appraisal and The Environment, Tinbergen Institute Discussion Paper TI, 2002-104/3

[23]. Raghu, T.S, et. al,Willingness To Pay in an Open Source Software Environment, Journal of Information System Research Vol 20, 2009, 218-236.

[24]. Rosen, Harvey S. dan Michael L. Katz. 1998. Microeconomics. McGraw-Hill Book Co, USA.

[25]. Setiawaty, E, et al, Infrastructure Development Strategy for Sustainable Wastewater System by Using SEM Method (Case Study Setiabudi and Tebet Districts, South Jakarta), Procedia Environmental Sciences, 2013, 685-692

[26]. Sylvie Démurger, et all, The relative contributions of location and preferential policies in China's regional development: being in the right place and having the right incentives, 2002, $444-465$

[27]. Yungfeng, Li, and Guohui, Song, The Effect of Reinforcing the Concept of Circular Economy in West China Environmental Protection and Economic Development, Procedia Environmental Sciences 12, 2012,785-792 